Viacheslav I. Vasenev' ${ }^{1}$ Alexey M. Yaroslavtsev ${ }^{1,2}$, Ivan I. Vasenev ${ }^{1,2}$, Sofiya A. Demina', Elvira A. Dovltetyarova'

'People's Friendship University of Russia, Miklukho-Maklaya str.6, Moscow, 117198, Russia

${ }^{2}$ Russian State Agrarian University - Moscow Timiryazev Agricultural Academy, Timiryazevskaya st., 49, Moscow, 127550, Russia

\title{
LAND-USE CHANGE IN NEW MOSCOW: FIRST OUTCOMES AFTER FIVE YEARS OF URBANIZATION
}

ABSTRACT. Urbanization coincides with remarkable environmental changes, including conversion of natural landscapes into urban. Moscow megapolis is among the largest urbanized areas in Europe. An ambitious New Moscow project expanded the megapolis on extra $1500 \mathrm{~km}^{2}$ of former fallow lands, croplands and forests. The research aimed to monitor land use changes in New Moscow between 1989 and 2016 years. Landsat 5 and Landsat 8 images (30 m spectral resolution) and Sentinel - 2 images (10 m spectral resolution) were analyzed. All the images were collected for the similar summer period (from June to August). The images were preprocessed and classified by Semi-Automatic Classification Plugin in open source QGIS software to derive land cover maps. The following land cover classes were identified: water, built-up areas, bare soils, croplands and forested areas, and the total area covered by each class was estimated. The following land-use change pathways were reported: 1) reduction of the forested areas by $2.5 \%$ (almost 2000 ha) between 1989 and 1998; 2) partial reforestation (more than 1000 ha) and abandonment of croplands (more than 3000 ha) between 1998 and 2010 and 3) intensive urbanization (more than 11000 ha) between 2010 and 2016. New build-up areas and infrastructures were constructed on former forested areas and croplands. Although, some uncertainties in the absolute estimates are expected due to the classification errors, the general urbanization trend can be clearly distinguished as a principal outcome after the five years of New Moscow project.

KEY WORDS: land use and land cover change, deforestation, supervised classification, satellite images, Landsat, urban planning, sustainable development

CITATION: Viacheslav I. Vasenev, Alexey M. Yaroslavtsev, Ivan I. Vasenev, Sofiya A. Demina, Elvira A. Dovltetyarova (2019) Land-Use Change In New Moscow: First Outcomes After Five Years Of Urbanization. Geography, Environment, Sustainability, Vol.12, No 4, p. 24-34 DOI-10.24057/2071-9388-2019-89

INTRODUCTION

Global urban population increases continuously and about 70 percent of the world's population will live in cities by
2050 (FAO 2009). Urbanization coincides with remarkable environmental, social and economic consequences (Turner 2002; Foley et. al., 2005). Conversion of the former agricultural and forested lands into urban 
areas is one of the main outcomes. An intensive urbanization in coming decades is projected in the developing countries and regions (FAO 2002). As a result, these countries will face numerous challenges in meeting the needs of the growing urban populations, including the demands for housing, infrastructure, transportation, energy, and employment, as well as for basic services such as education and health care (U.N. 2014).

The urban expansion occurs on former natural and forested areas and often coincides with deforestation. The rate of deforestation process is increasing every year and it brings a big change in the earth's physical and chemical environments (Kumar 2017). The tree canopies perform as barriers for dust, noise and pollution (U.N. 2014) and maintain the temperature regime of the forest ecosystem (FAO 2018). Tree roots help to hold soil particles together and mitigate soil erosion (Bond, Hughes 2013). Forests contribute to water balance by controlling the precipitation distribution between surface run-off and ground waters (Kalnay, Cai 2003). Cutting the forests down decreases this protective service, disturbs nutrient cycles and increases greenhouse gases' emission (Hendesron-Sellers 2009; Bond, Hughes 2013). Deforestation of the suburbs results in substantial changes in the urban climate and contributes to urban heat island (Kalnay, Cai 2003; Oke 1982; Voogt, Oke 2003). Urban heat island decreases the comfort and quality of life in cities and causes the extra costs for cooling (Sarrat et.al. 2006; Tan et.al. 2010; Kolokotroni et. al., 2006; Chen et. al. 2016).

Urban green spaces include places with 'natural surfaces' or 'natural settings', but may also include specific types of urban greenery, such as street trees and green lawns. Typical green spaces in urban and sub-urban areas are public parks and urban forests; other definitions may also include private gardens, woodlands, children's play areas, riverside footpaths, beaches, and so on (WHO 2014). Under the condition of growing or even stable population, deforestation would reduce the total area of green spaces per capita (Gracey 2003). Decreasing of the green areas per capita below minimal thresholds can create health risks for population (SniP II-60-75 Russian Federation). The most likely negative consequences for human health are insufficient physical activity, depression, respiratory diseases and allergic reactions (WHO 2014).

Monitoring land-use changes and studying their consequences are especially interesting and relevant in the regions with ongoing urbanization. New Moscow is a unique area, which has been experiencing a rapid urbanization during last five years since 2012. Remarkable development of new urban infrastructure in New Moscow coincides with conversion of fallow, agricultural and forested lands into build-up areas. The aim of the research was to analyze the land-use changes dynamics in the current New Moscow area between 1989 and 2016 and to investigate the land-use change and environmental consequences of New Moscow project.

\section{MATERIAL AND METHODS}

Deforestation of suburban areas is a continuous non-linear process, that shall be considered to select a relevant monitoring approach. Federal State Statistics Service provides information about land-use change annually but lacks spatial explicitness and doesn't allow following rapid changes occurring in short time periods. Similarly, land-use change studies based on the existing cartographic maps will not catch up with the ongoing rapid land-use changes like urbanization (Sivtsov 2014). In comparison to census data and cartographic maps, a remote sensing approach and GIS-based solutions give a considerable advantage to obtain more detailed information with an appropriate frequency (Frelinger, Gabriele 1999; Lurie et al. 2017). Open access to data is available from many official sources, which provide satellite imagery free of charge, e.g USGS Earth Explorer, NOAA CLASS; NASA; EOLi. Remote sensing data is widely used for land use monitoring and agricultural purposes (Hadjimitsis et.al. 2010; Liang et.al. 2008). Implementing remote sensing approaches to monitor urbanization and estimate its environmental consequences is getting increasingly relevant 
Research area. New Moscow extends from 으 $54^{\circ} 55^{\prime} \mathrm{N}$ to $55^{\circ} 61^{\prime} \mathrm{N}$ latitudes and from $36042^{\prime}$ to $37071^{\prime}$ longitudes Southwest of the Moscow city and covers an area of more than 148 thousand hectares, which was officially included into the Moscow city boundaries in 2012 (Fig. 1). The climate is temperate continental, summer is warm, winter is moderately cold. Before 2012, less than 10\% of the New Moscow areas was urbanized, whereas forests and croplands had covered 51 and 17\% of the areas respectively. New Moscow forests mainly belong to the category of mixed forest. Birches (Betula pendula, Betula alba), alders (Alnus inana), firs (Picea abies), pines (Pinus sylvestris), maples (Acer platanoides), oaks (Quercus robus), lindens (Tilia cordata) and aspens (Populus tremula) are the most spread species (Vasilev and Chistov 2016). Grain, row and vegetables are the most spread crops in the region. Soils in the region are dominated by Retisols (Shishov and Voitovich 2002; FAO 2006).

As a result of the New Moscow Project, the area of Moscow city increased by almost 2.5 times. In 2012-2018, more than 8 million $\mathrm{m}^{2}$ of housing, 2.8 million $\mathrm{m}^{2}$ of non-residential property objects, 47 public facilities and 2 metro stations have been constructed and completed. The development potential is estimated as 63.9 million $\mathrm{m}^{2}$ for new working places, 89.8 million $\mathrm{m}^{2}$ for residences and $1156 \mathrm{~km}$ for the construction and reconstruction of roads. By 2035, it is planned to build $65 \mathrm{~km}$ of metro tracks and to open 29 new metro stations (Privezentseva and Tesler 2015). Established infrastructure and created working places attract labor migration and lead to redistribution of population inside Moscow, especially parts of the New Moscow neighboring old Moscow boundaries (Makhrova and Kirillov 2018). With all these achieved and planned activities, New Moscow is for sure the most ambitious urbanization project in Russia.

Datasets. The datasets used in the study was derived from a sequence of satellite images from 1989, 1994, 1998, 2007, 2010, 2015 and 2016 taken by Landsat 5, Landsat 8 or Sentinel 2 (Table 1). The resolution of images allows to detect land use and land cover (LULC) categories of the study area.

Image Classification methods. The supervised classification approach was used to classify the land-use types. The following research steps were taken: 1) the pre-processing operations (including atmospheric correction and clipping); 2) supervised classification of images; 3) classification accuracy evaluation and 4) estimation of the forested areas. Supervised classification algorithm is presented on Fig. 2.

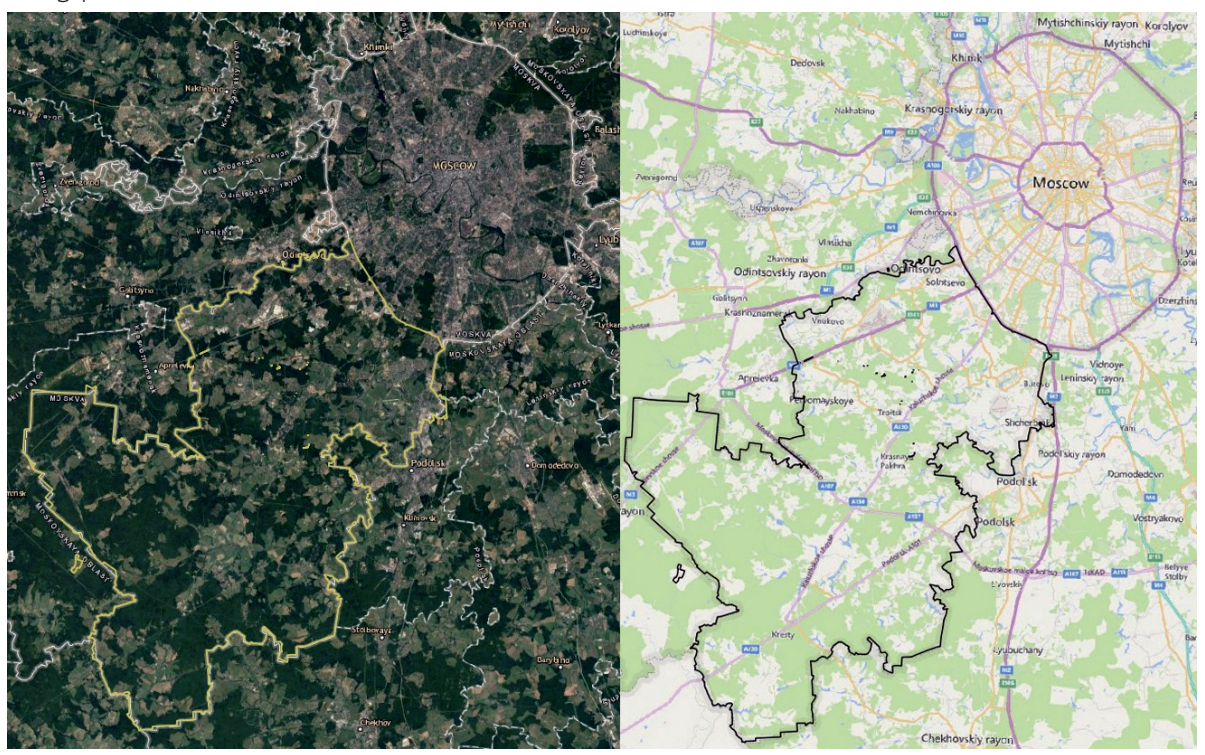

Fig. 1. Geographic location of study area (QGIS, Quick Map Services plugin, Google Satellite, ESRI Boundaries \& Places, Bing Map) 
Table 1. Comparative characteristics of satellite images (Images taken from USGS official website)

\begin{tabular}{|c|c|c|c|}
\hline Satellite & Sentinel-2 & Landsat-5 & Landsat-8 \\
\hline & & $\begin{array}{l}03 / 06 / 1989 \\
30 / 07 / 1998 \\
24 / 08 / 2007 \\
15 / 07 / 2010\end{array}$ & $26 / 05 / 2015$ \\
Date & $07 / 24 / 2016$ & $30 \mathrm{~m}$ & $30 \mathrm{~m}$ \\
\hline $\begin{array}{c}\text { Spatial resolution } \\
\text { (meters) }\end{array}$ & $10 \mathrm{~m}$ & & \\
\hline
\end{tabular}

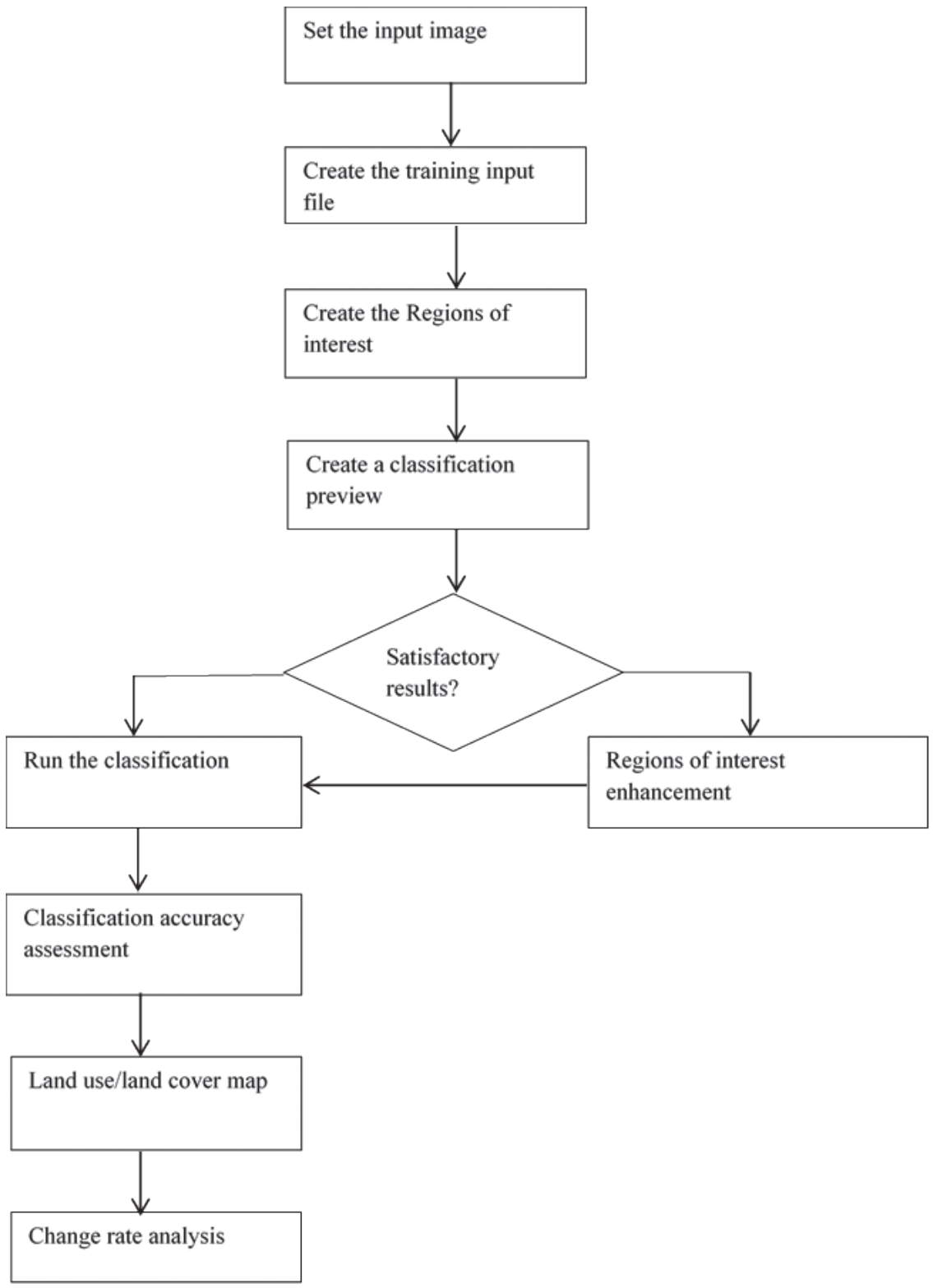

Fig. 2. Supervised classification workflow 
Atmospheric correction of remote sensing

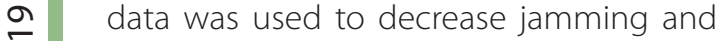
deterioration of images by smoothing and minimizing distortion, cloudiness and the effect of water vapor (Fallati et. al., 2017). Only the images collected during the similar period (growing season) were used to increase the comparability between the years. Correction and classification were performed using Semi-Automatic Classification Plugin. Land cover for selected the time periods between 1989 and 2016 was classified into 4 categories - forested, built-up, agricultural (including bare soils) and water bodies. The adopted classification is hierarchical with two levels of detail: Level I (macroclasses) and Level II (micro-classes). The images for each observation period were classified into 4 macro-classes: water, built-up, crops (including bare soil area) and forest. Classification was performed using Minimum Distance algorithm. The spatial accuracy of the classified maps was checked using Error Matrix by creating randomly scattered 100 points for every observation period. These points were overlaid on the classified images. All preprocessing operation, Error Matrix creation and classifying raster maps conversion to shape files were performed using Semi-Automatic Classification Plugin.

We assume that 1) the rate of urbanization expansion could increase considerably from 2012 to 2016 compared to the other time periods; 2) deforestation and urbanization processes in New Moscow are interrelated.

\section{RESULTS AND DISCUSSION}

Land-use change pathways in New Moscow in 1989-2016. Land-use maps were derived from the satellite images for each of the observation periods and an overlay between the maps from different periods allowed illustrating the major landuse change pathways. Three land-use categories - forested areas, croplands and urban (build-up) areas experienced the most considerable changes during the entire observation period and the land-use structure of the New Moscow territory in 2016 is considerably different compared to the first observation period in 1989. Urban expansion was obviously the dominating trend in the area. The total build-up area increased almost two times - from 1.3 to $2.4 \mathrm{~km}^{2}$. The major part of new build-up areas was developed within approximately $30 \mathrm{~km}$ from the Moscow city (boundaries before 2012), whereas urban expansion in the remote parts of the region were less intensive. The forested area in 2016 was $0.26 \mathrm{~km}^{2}$ less than in 1989, evidencing that $3.5 \%$ of the initial forest resources were lost during this period. Cropland areas also decreased on $0.2 \mathrm{~km}^{2}$, which is more than 4\% of the arable lands in 1989 (Fig. 3).

Comparison between 1989 and 2016 highlights the major land-use change outcomes but does not describe landuse dynamic inside this period, which is important to understand the drivers behind land-use change in the region. When the maps derived for all the observation periods were compared, the following land-use change pathways were found: 1) forested areas converted to builtup areas; 2) forested areas converted to croplands; 3) croplands converted to builtup areas (fig.4). None of these land-use change pathways remained linear for the whole observation periods but increased or decreased the intensity or even changed to a reverse land-use change in result of social-economic impacts and political decisions. Several periods with different dominating land-use change pathways can be distinguished. During the period between 1989 and 1998, cropland increased on more than $1.1 \mathrm{~km}^{2}$, whereas the forested areas decreased on approximately $0.1 \mathrm{~km}^{2}$. This can be an evidence of the intensification of agriculture in the Moscow region by 1998 after its collapse in the beginning on 1990s, which could partly occur on former forested areas (e.g., non-protected forests). In 1998-2010 the opposite trend was observed - forested areas increased on $0.1 \mathrm{~km}^{2}$ and cropland decreased on comparable $0.33 \mathrm{~km}^{2}$. Partly, this outcome can be explained by reforestation of the abandoned croplands, which profitability in the Moscow region 


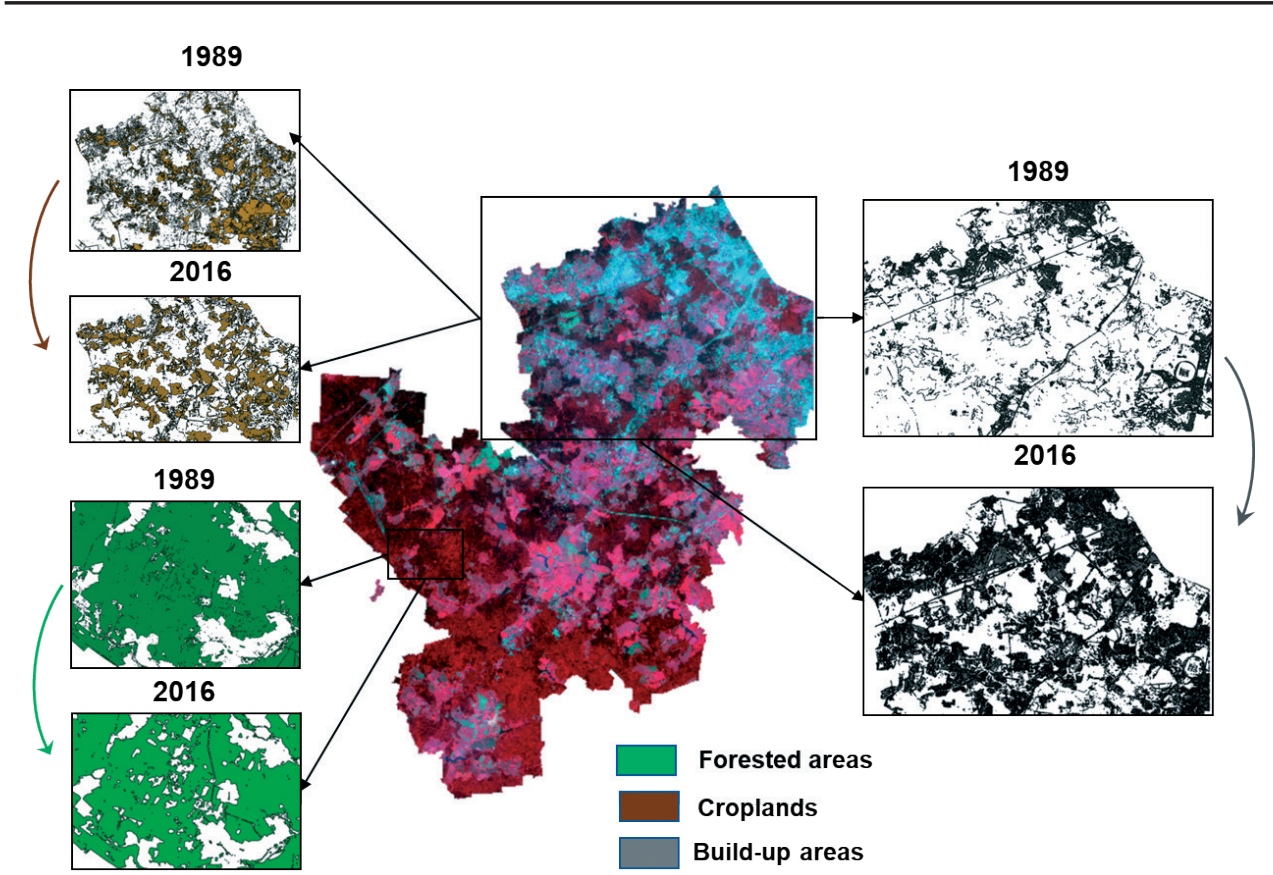

Fig. 3. Changes in forested areas, croplands and build-up areas in New Moscow between 1989 and 2019

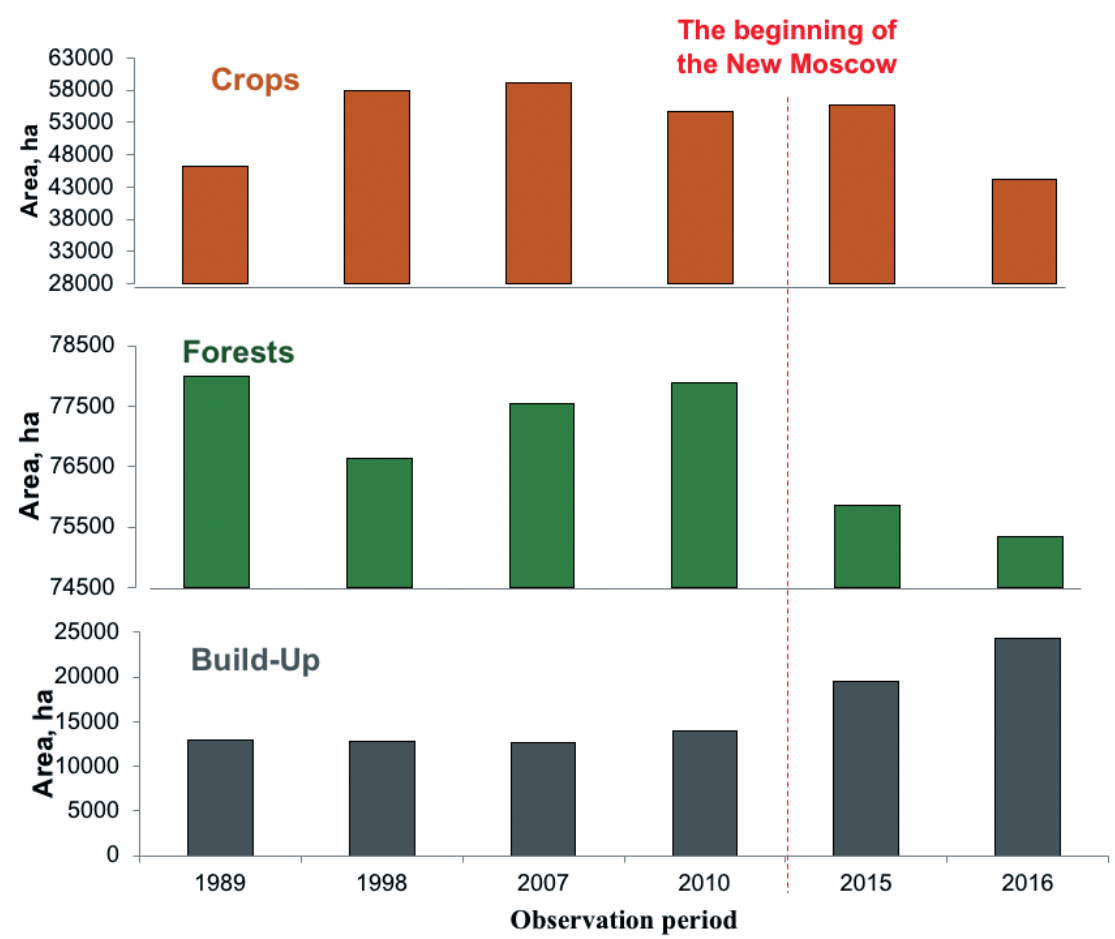

Fig. 4. Land-use change dynamics in New Moscow during the period 1989-2019

is rather low. Interestingly, during twenty years between 1989 and 2010 the extent of build-up areas increased just on 0.09 $\mathrm{km}^{2}$ or by $7 \%$ from the initial urban area.
However, the next period between 2012 and 2016 showed a rapid urbanization on more than $1.1 \mathrm{~km}^{2}$ (86\% of build-up areas in 2010). Apparently, this urbanization 
occurred on former forested areas and croplands, which extent decreased on 0.25 and $1.0 \mathrm{~km}^{2}$ correspondingly during this time period.

Data accuracy and uncertainties of projections. Several sources of uncertainty of the obtained estimates could be expected. The primary one is the classification error. To check the classification accuracy was checked by a routine procedure based on the Kappa hat criteria measured based on the comparison between observed and expected estimates. The output table (Table 2) includes overall accuracy, producer and user accuracy for each established macroclasses. Overall classification accuracy 2007, 2010, 2016 classification exceeds 85 $\%$, that is minimum level of interpretation accuracy in the identification of land use and land cover categories from remote sensor. Further, the outcomes of the remote sensing analysis were compared to the census data to validate and explain the found land-use changes. One of the main indicators for the building construction sphere is the established dwellings $(\mathrm{m} / \mathrm{n}$. square meters of total floor space of dwellings). This indicator characterizes a housing stock development at the end of the year. We compared this indicator to the extents of build-up areas projected by remote-sensing approaches and obtained a significant correlation ( $r=0.89)$ between the values. This confirms that the reported urbanization trend was correct.
Besides, the approach we used is focused on the land conversion between the macroclasses (forested areas, croplands and build-up areas), whereas changes in microclasses were estimated with less accuracy and therefore could cause additional errors. For example, in the period between 1998 and 2010 an increase in the total area of the forests was reported. However, a detailed study of the high-resolution images available from the resource Google Earth Pro space images, explained this outcome by the gradual "reforestation" of felling sites. The figure 5 gives an example of a specific forest site which was cut down in the 80-s and abandoned afterwards. They stood out against the background of a common array, young shoots were rare and crown not lush enough. Considering these properties and the spatial resolution of satellite images (30 m per pixel), the algorithm did not classify such areas to the "forest" macro-class until 2007. Only the results of the classification for 2010 showed that these areas were recognized as forested again (Fig.5).

Finally, the negative consequences of urbanization are not limited to the decrease in the quantity of forested areas, but also alter the quality of forests, change their structure and deplete the ecosystem services they provide (DeFries and Pandey 2010; Lyu et al. 2018). Defragmentation of the forested areas activates the "edge erosion" when the forested areas

Table 2. Classification accuracy (Error Matrix)

\begin{tabular}{|c|c|c|c|c|c|c|c|}
\hline $\begin{array}{c}\text { Observation } \\
\text { period }\end{array}$ & $\begin{array}{c}\text { Overall } \\
\text { classifi- } \\
\text { cation } \\
\text { accuracy } \\
{[\%]}\end{array}$ & $\begin{array}{c}\text { Macroclass } \\
\text { 'Forest' } \\
\text { producer } \\
\text { accuracy } \\
{[\%]}\end{array}$ & $\begin{array}{c}\text { Macroclass } \\
\text { 'Forest'user } \\
\text { accuracy } \\
{[\%]}\end{array}$ & $\begin{array}{c}\text { Macroclass } \\
\text { 'Crops' } \\
\text { producer } \\
\text { accuracy } \\
{[\%]}\end{array}$ & $\begin{array}{c}\text { Macroclass } \\
\text { 'Crops' user } \\
\text { accuracy } \\
{[\%]}\end{array}$ & $\begin{array}{c}\text { Macro- } \\
\text { class } \\
\text { 'Forest' } \\
\text { Kappa } \\
\text { hat }\end{array}$ & $\begin{array}{c}\text { Macro- } \\
\text { class } \\
\text { 'Crops' } \\
\text { Kappa } \\
\text { hat }\end{array}$ \\
\hline 1989 & 78.84 & 92.31 & 80.00 & 95.65 & 88.00 & 0.73 & 0.78 \\
\hline 1998 & 77.98 & 91.79 & 84.40 & 65.10 & 64.14 & 0.59 & 0.49 \\
\hline 2007 & 87.50 & 99.70 & 83.33 & 77.78 & 87.00 & 0.71 & 0.80 \\
\hline 2010 & 95.71 & 99.80 & 99.80 & 91.18 & 81.58 & 0.98 & 0.79 \\
\hline 2016 & 94.15 & 93.84 & 99.05 & 95.93 & 89.11 & 0.98 & 0.83 \\
\hline
\end{tabular}




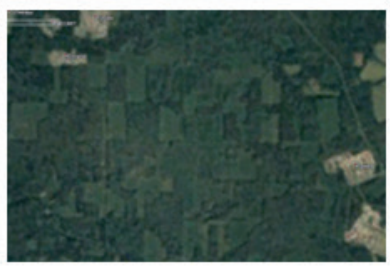

$08 / 08 / 2004$

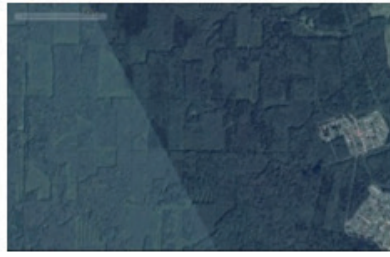

$08 / 28 / 2016$

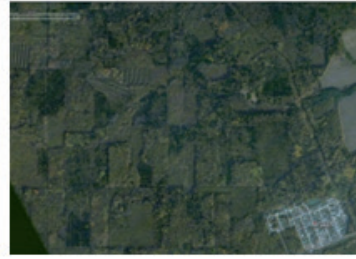

$07 / 23 / 2008$

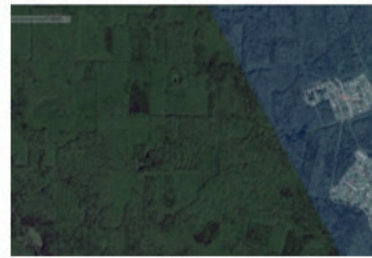

$05 / 22 / 2017$

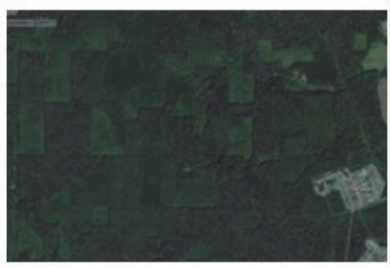

$07 / 13 / 2014$

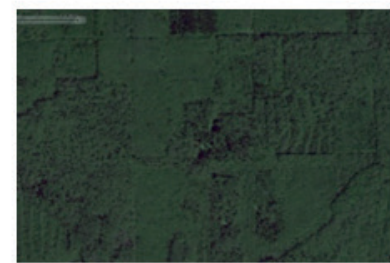

05/22/2017-zoomed image

Fig. 5. Regeneration of the cutting area in the South-Western part of the study region (images are taken using Google Earth Pro service).

neighboring urban areas get exposed to high anthropogenic load resulting in biodiversity loss and simplification of the vertical structure (Rysin et al. 2004). Deforestation followed by intensive development of urban infrastructure (i.e., building construction, development of roads and railways) creates further risks for air quality (Belyakov and Koldobskaya, 2018), soil degradation (Romzaykina et al. 2020), biodiversity loss (Demina et al. 2019) and erosion (Daykovskaya 2014). All these multiple consequences shall be taken into consideration for sustainable urban development in New Moscow.

\section{CONCLUSION}

Ongoing urbanization alters landuse structure globally and regionally. New buildings and infrastructures are developed on former agricultural and forested lands to satisfy the demand of growing population in place for settlement. New Moscow projects is a unique case of the tremendous increase of urbanization intensity by a political decision. Landuse change dynamics observed in the region between 1989 and 2010 changed considerably in 2010-2016 when the New Moscow project was started. The build- up area remaining invariable for almost twenty years increased two times during the following six years. The extent of the agricultural and forested areas decreased to a total $1.25 \mathrm{~km}^{2}$ for the same period. Although some uncertainties in the absolute estimates are expected due to the errors in semi-Automatic Classification and land cover dynamics inside the distinguished land-use classes, the general tendency of an intensive urbanization is clear and confirmed by a strong correlation with a census data on the new dwellings put in place. A rapid urbanization on former croplands and forested areas can result in depletion of important ecosystem services, which shall be considered for such ambitious projects as New Moscow.

\section{ACKNOWLEDGEMENTS}

The remote sensing analysis was supported by Russian Science Foundation, project No. 19-77-30012. Modeling and validation were supported by the RFBR project No 1835-20052. The authors would like to thank MSc Irina Veretelnikova for her essential contribution to remote sensing analysis, which was at the basis of the presented research. 


\section{REFERENCES}

Bityukova V.R., Koldobskaya N.A. (2018). Environmental factors and constrains in the development of the new territory of Moscow (so-called "New Moscow"). Geography, Environment, Sustainability, 11(2), 46-62. DOI: 10.24057/2071-9388-2018-11-2-46-62

Bond T., Hughes C. (2013). O-level Biology Challenging Practice Solutions (Yellowreef). London: Yellow reef Limited.

Chen L., Huang L., Mendez-Garcia C., Kuang J., Hua Z., Liu J., and Shu W. (2016). Microbial communities, processes and functions in acid mine drainage ecosystems. Current Opinion in Biotechnology, 38, 150-158, DOI: 10.1016/j.copbio.2016.01.013.

Daykovskaya T.S. (2014). Assessment of gully network current state in the New Moscow area. Geomorphology, 4, 39-47, DOI: 10.15356/0435-4281-2014-4-39-47.

DeFries R., Pandey D. (2010). Urbanization, the energy ladder and forest transitions in India's emerging economy. Land Use Policy, 27 (2), 130-138, DOI: 10.1016/j.landusepol.2009.07.003.

Demina S., Vasenev V., Ivashchenko K., Ananyeva N., Plyushchikov V., Hajiaghayeva R., Dovletyarova E. (2018). Microbial properties of urban soils with different land-use history in New Moscow. Soil Science, 4, 132-140, DOl: 10.21657/tsd.47684.

Fallati L., Savini A., Sterlacchini S., Galli P. (2017). Land use and land cover (LULC) of the Republic of the Maldives: first national map and LULC change analysis using remotesensing data. Environmental Monitoring and Assessment, 189(8), 417, DOl: 10.1007/ s10661-017-6120-2.

FAO. (2002). Urbanization - Linking Development Across the Changing Landscape. Axel W. Drescher, David laquinta, Julio Dávila, Adriana Allen, Fred Kruger and the Comparative Agricultural Development Service (ESAC), http://www.fao.org/fileadmin/templates/FCIT/ PDF/sofa.pdf).

FAO. (2006) World reference base for soil resources 2006. World Soil Resources Reports, 103, Rome.

FAO. (2009). Population and development review, 35 (4), 837-839.

FAO. (2018). FRA team-Lead author Monica Garzuglia. Seventy years of FAO's Global Forest Resources Assessment (1948-2018), Roma, Italy.

Foley A.J. et al. (2005). Global consequences of land use. Science 309, 570-574, DOI: 10.1126/science.1111772.

Frelinger D. R., Gabriele M. (1999). Remote Sensing Operational Capabilities: Final Report. RAND.

Gracey M. (2003). Child health implications of worldwide urbanization. Rev Environ Health, 18(1), 51, DOI: 10.1515/reveh.2003.18.1.51.

Hadjimitsis D. G., Papadavid G., Agapiou A., Themistocleous K., Hadjimitsis M. G., Retalis A., Michaelides S., Chrysoulakis N., Toulios L. and Clayton C. R. I. (2010). Atmospheric correction for satellite remotely sensed data intended for agricultural applications: impact on vegetation indices. Natural Hazards and Earth System Sciences, 10, pp. 89-95, DOI: 10.5194/nhess-10-89-2010. 
Henderson-Sellers A., Dickinson R. E., Wilson M. F. (2009) Tropical deforestation: important processes for climate models, Climate change, 13(1), 43-67, DOI: 10.1007/BF00140161.

Kalnay E., Cai M. (2003). Impact of urbanization and land-use change on climate. Nature 423 (6939), 528-531, DOl: 10.1038/nature01675.

Kolokotroni M., Giannitsaris I. and Watkins R. (2006). The effect of the London urban heat island on building summer cooling demand and night ventilation strategies. Solar Energy, 80. 383-392, DOl: 10.1016/j.solener.2005.03.010.

Kumar D. (2017). Monitoring and assessment of land use and land cover changes (1977 2010) in Kamrup district of Assam. India using remote sensing and GIS techniques, 15 (3), 221-239, DOI: 10.15666/aeer/1503_221239.

Liang T., Zhang X., Xie H., Wu C., Feng Q., Huang X. and Chen Q. (2008). Toward improved daily snow cover mapping with advanced combination of MODIS and AMSR-E measurements. Remote Sensing of Environment, 112, 3750-376, DOI: 10.3390/rs5115463.

Lurie I.K., Prokhorova E.A., Semin V.N., Sakirkina M.A. (2017). Provision of web-cartographic support for the ecological and geographical assessment of the New Moscow territory development. Vestnik Moskovskogo universiteta, ser. Geografiya, 5, 49-57 (in Russian).

Lyu R., Zhang J., Xu M., Li J. (2018). Impacts of urbanization on ecosystem services and their temporal relations: A case study in Northern Ningxia, China. Land Use Policy, 77, 163-173, DOI: 10.1016/j.landusepol.2018.05.022.

Makhrova A.G., Kirillov P.L. (2018). New Moscow: old and new features of social-economic development. In Old and New Moscow: tends and problems of development. IP Matushkin I.I. Publisher, 89-119.

Oke, T.R. (1982). The Energetic Basis of the Urban Heat Island. Quarterly Journal of the Royal Meteorological Society, 108, 1-24, DOI: 10.1002/qj.49710845502.

Privezentseva S.V., Tesler K.I. (2015). Features of Public Transport Availability Organization for Big Cities (on the Example of "New Moscow"). Proceedings of Moscow State University of Civil Engineering, 6, 115-123 (In Russian).

Romzaykina O., Vasenev V., Andrianova D., Neaman A., Gosse D. (2020). The Effect of Sealing on Soil Carbon Stocks in New Moscow. Springer Geography, 29-36, DOl: 10.1007/978-3030-16091-3_5.

Rysin L.P., Saveleva L.I., Rysin S.L. (2004). Forest monitoring in urbanized areas. Russian journal of ecology, 4, 209-213.

Sarrat C., Lemonsu A., Masson V. and Guedalia D. (2006). Impact of urban heat island on regional atmospheric pollution. Atmospheric Environment, 40, 1743-1758.

Shishov L., Voinovich N. (2002). Soils of Moscow Region and Their Use. Dokuchaev Soil Science Institute, Moscow.

Sivtsov I.A. (2014). Economic approval behind establishing boundaries and extents of new territories of Moscow city. PhD thesis in economy and land planning, Moscow.

SniP $\|-60-75^{* *}$. Building codes and regulations. Design standards. Planning and construction of cities, towns and rural settlements. 
Tan D. S. H., Ang Y., Lim G. S., Ismail M. R. B. and Meier R. (2010). From 'crypticspecies' to integrative taxonomy: an iterative process involving DNA sequences, morphol-ogy, and behaviour leads to the resurrection of Sepsis pyrrhosoma (Sepsidae: Diptera). Zoologica Scripta, 39, 51-61, DOI:10.1111/j.1463-6409.2009.00408.x.

Turner BL II. (2002). Toward integrated land-change science: Advances in 1.5 decades of sustained international research on land-use and land cover change. Challenges of a Changing Earth. Berlin: Springer, 21-26.

U. N., Department of Economic and Social Affairs, Population Division (2014). World Urbanization Prospects: The 2014 Revision, Highlights (ST/ESA/SER.A/352).

Vasilev O.D., Chistov S.V. (2016). The study and mapping of environmental functions of forests in New Moscow. Izvestiya vysshih uchebnyh zavedenij Geodeziya i aehrofotosemka, 60(5), 128-133 (in Russian).

Voogt J.A., Oke T.R. (2003). Thermal remote sensing of urban climates. Remote Sensing of Environment, 86, 370-384, DOI: 10.1016/S0034-4257(03)00079-8.

World Health Organization. (2014). Global status report on noncommunicable diseases. town-planning policy and construction complex of Moscow city. https://stroi.mos.ru/ new-moscow 